\title{
Correction to: Integrated processing of ground- and space-based GPS observations: improving GPS satellite orbits observed with sparse ground networks
}

\author{
Wen Huang $^{1,2}$ (D) . Benjamin Männel ${ }^{1} \cdot$ Pierre Sakic $^{1}$ (D) $\cdot$ Maorong Ge $^{1,2} \cdot$ Harald Schuh $^{1,2}$
}

Published online: 30 August 2021

(c) Springer-Verlag GmbH Germany, part of Springer Nature 2021

\section{Correction to: Journal of Geodesy (2020) 94:96 https://doi.org/10.1007/s00190-020-01424-1}

The article Integrated processing of ground- and space-based GPS observations: improving GPS satellite orbits observed with sparse ground networks, written by Wen Huang, Benjamin Männel, Pierre Sakic, Maorong Ge \& Harald Schuh was originally published electronically on the publisher's internet portal on [10 October 2020] without open access. With the author(s)' decision to opt for Open Choice, the copyright of the article changed on [10 May 2021] to () The Author(s) 2020 and the article is forthwith distributed under a Creative Commons Attribution Open Access funding enabled and organized by Projekt DEAL.
Open Access This article is licensed under a Creative Commons Attribution 4.0 International License, which permits use, sharing, adaptation, distribution and reproduction in any medium or format, as long as you give appropriate credit to the original author(s) and the source, provide a link to the Creative Commons licence, and indicate if changes were made. The images or other third party material in this article are included in the article's Creative Commons licence, unless indicated otherwise in a credit line to the material. If material is not included in the article's Creative Commons licence and your intended use is not permitted by statutory regulation or exceeds the permitted use, you will need to obtain permission directly from the copyright holder. To view a copy of this licence, visit http://creativecommons.org/licenses/by/4.0/.

The original article can be found online at https://doi.org/10.1007/ s00190-020-01424-1.

\footnotetext{
Wen Huang

wen.huang@gfz-potsdam.de

1 Deutsches GeoForschungsZentrum GFZ, Telegrafenberg, 14473 Potsdam, Germany

2 Institute of Geodesy and Geoinformation Science, Technische Universität Berlin, Strasse des 17. Juni 135, 0623 Berlin, Germany
} 